\title{
Toxicological evaluation of Lafoensia pacari A. St.-Hil. (Lythraceae) stem bark extract: Acute and subchronic studies in mice
}

\author{
Renato Ivan de Ávila1, Camila Carvalho Ferreira', Cátia Belo Mattos Alvarenga1, \\ Marcelo de Sousa Vieira ${ }^{1}$, Alane Pereira Cortez ${ }^{1}$, Aline Carvalho Batista ${ }^{2}$, Elson Alves Costa ${ }^{3}$, \\ Marize Campos Valadares ${ }^{\oplus 1, *}$
}

\begin{abstract}
${ }^{1}$ Laboratory of Cellular Toxicology and Pharmacology - FarmaTec, Faculty of Pharmacy, Federal University of Goiás, Goiânia, GO, Brazil, '² Department of Stomatology (Oral Pathology), Dental School, Federal University of Goiás, Goiânia, GO, Brazil, ${ }^{3}$ Institute of Biological Sciences, Department of Physiological Sciences, Federal University of Goiás, Goiânia, GO, Brazil
\end{abstract}

\begin{abstract}
This study evaluated the safety of Lafoensia pacari A. St.-Hil. (Lythraceae) stem bark hydroalcoholic extract (LPE) through acute and subchronic toxicological assessments in mice. In the acute toxicity evaluation, a single $2000 \mathrm{mg} / \mathrm{kg}$ oral dose of LPE was administered to mice and clinical observations were conducted for 14 days. For subchronic toxicity, LPE doses $(6.25-1000 \mathrm{mg} / \mathrm{kg})$ were administered orally for 28 days and biochemical, hematological, histopathological analyses and renal and liver expression of Ki-67 were carried out. The acute oral toxicity evaluation of LPE showed no toxicity in mice and it was was classified as category $5\left(\mathrm{LD}_{50}>2000-5000 \mathrm{mg} / \mathrm{kg}\right)$. In a repeated dose 28-day toxicity study, LPE (100-1000 mg/kg) led to an increase in reticulocytes, which suggests a possible proliferative effect on blood cells. In addition, LPE (400-1000 mg/kg) of produced alterations in biochemical parameters, although no microscopic changes were found in the organs analyzed. A normal expression of the Ki-67 cell proliferation indicator was observed in the kidney and liver tissues, which suggests that LPE does not bring about changes in the proliferative activity of these organs. In conclusion, LPE should be used with caution, particularly in larger doses over longer periods and also in combination with other medication.
\end{abstract}

Keywords: Mangava-brava. Lafoensia pacari/evaluation. Medicinal plant. Natural product.

\section{INTRODUCTION}

Lafoensia pacari A. St.-Hil. (Lythraceae), popularly known as mangava-brava or pacari, is a medicinal plant found in the Cerrado biome, the Brazilian savanna. Its stem bark has been used to treat gastric ulcers, cancer, diarrhea, kidney diseases and inflammatory processes in Brazilian popular medicine (Proença, Oliveira, Silva, 2000; Solon et al., 2000; Lima et al., 2006a; Nascimento et al., 2011).

Phytochemical analyses carried out on Lafoensia pacari stem bark hydroalcholic extract (LPE) have demonstrated the presence of tannins, saponins, steroids, triterpenes and flavonoids (Galdino et al., 2009; 2015).

\footnotetext{
*Correspondence: M. C. Valadares. Faculdade de Farmácia, Universidade Federal de Goiás. Rua 240 esquina com $5^{\mathrm{a}}$ Avenida, s/n, Setor Universitário, CEP: 74605.170 - Goiânia, GO, Brazil. Phone / fax: +55 62 3209-6039 ext. 202. E-mail:marizeufg@gmail.com
}

In addition, several other phytochemicals have been identified in hydroalcoholic extract preparations, as well as their organic fractions, such as chalcones, aurones, free xanthones, heterosides, leucoanthocyanidins, anthraquinones, 3-O- $\beta$-D-glucopyranoside, gallic acid and ellagic acid, which is the main active compound of this plant (Solon et al., 2000; Lima et al., 2006b; Rogerio et al., 2006; Galdino et al., 2009; 2015; Nascimento et al., 2011; Sampaio et al., 2011; Tamashiro Filho et al., 2012).

Scientific studies have corroborated the popular use of $L$. pacari stem bark as an anti-inflammatory agent (Rogerio et al., 2006; Matos et al., 2008; Rogerio et al., 2008a) through the inhibition of inflammatory parameters such as interleukin-5 and eosinophil migration (Rogerio et al., 2003; 2008b; Rogerio, Sá-Nunes, Faccioli, 2010). In vivo studies have also reported antiulcer activity, associated, at least in part, with two different mechanisms: a dependent mechanism of the antioxidant and anti- 
secretory properties and inhibition of pro-inflammatory cytokines; and an independent mechanism of gastric/ intestinal motility and mucus secretion (Tamashiro Filho et al., 2012). Certain studies have also highlighted other significant activities, which include in vitro free radical scavenging (Solon et al., 2000), anticancer (Marcondes et al., 2014) and antimicrobial potential (Lima et al., 2006a; 2006b; Silva Junior et al., 2010; Pereira et al., 2011; Queiroz e Silva et al., 2012). In addition, analgesic and anti-oedematous effects (Rogerio et al., 2006), antidepressant-like activity (Galdino et al., 2009; 2015), sedating (Matos et al., 2008), antinociceptive effects, independent of anti-inflammatory activity (Matos et al., 2008; Nascimento et al., 2011) and wound healing effect (Pereira et al., 2018) have been shown.

Despite the above-mentioned scientific evidence, and the use of the L. pacari stem bark hydroalcoholic extract (LPE) in Brazilian popular medicine, the toxicity data on this plant are still scarce. With that in mind, this study evaluated the safety of LPE, through acute oral systemic toxicity and repeated dose 28-day toxicity studies in mice, since the most $L$. pacari preparations used by Brazilians are made using stem bark maceration in alcoholic preparations (Galdino et al., 2015).

\section{MATERIAL AND METHODS}

\section{Obtaining LPE}

The stem bark was collected from $L$. pacari plants in Bela Vista, State of Goiás, Brazil (837 m, $16^{\circ} 58^{\prime} 54.2$ " S, $40^{\circ} 55^{\prime} 45.1$ ' W). The botanical material was authenticated by Dr. José Realino de Paula, and a voucher specimen was deposited at the Federal University of Goiás Herbarium (UFG no. 27031). LPE was obtained as previously described by Nascimento et al. (2011). In brief, the LPE was obtained through drying of stem bark pieces at $30-40{ }^{\circ} \mathrm{C}$ for $48 \mathrm{~h}$ and powdered. After that, it was carried out maceration in a $70 \%$ hydroalcoholic solution for $72 \mathrm{~h}$ and subsequent filtration. The solvent was then evaporated until dry under reduced pressure, giving extract with a yield of $16.1 \%(\mathrm{w} / \mathrm{w})$. In a previously published study, phytochemical analysis of LPE showed the presence of total phenols (18.9\%), flavonoids (4\%) and total tannins (16.7\%), being ellagic acid one of the phytochemicals present in the extract (Nascimento et al., 2011). The doses of LPE were immediately prepared by dilution in sunflower oil (vehicle) before administering to the animals, as recommended by OECD (2002).

\section{Animals}

The experimental protocols were approved by the Federal University of Goiás Research Ethics Committee for the Use of Animals (UFG N ${ }^{\circ} 137 / 2009$ ), in accordance with institutional procedures and guidelines of the Institutional Animal Care and Use Committee, which follows the recommendations of the Canadian Council on Animal Care (Olfert, Cross, Mcwilliam, 1993). Swiss male and female mice (body weight: $25-35 \mathrm{~g}$; age: 7-10 weeks) were obtained from the Bioterium at the Federal University of Goiás. All efforts were realized to ensure the welfare of animals. They were kept in constant environmental conditions with light-dark cycles and controlled temperature, and water and food were provided ad libitum. There were daily checks of changes in activity and behavior as a clinical indication of animal suffering to determine when they should be humanely sacrificed (Hubrecht, Kirkwood, 2010). At the end of each experiment, the mice were anesthetized with intraperitoneally administered xylazine $(10 \mathrm{mg} / \mathrm{kg})$ and ketamine hydrochloride $(100 \mathrm{mg} / \mathrm{kg}$ ) and then euthanized by cervical dislocation (Hubrecht, Kirkwood, 2010).

\section{Toxicity studies}

\section{Acute toxicity evaluation of LPE}

The acute oral toxicity of LPE was investigated according to OECD Guideline 423 (2002). This guideline recommends an alternative acute toxic class method focused on reducing animals use without reducing the scientific integrity of data obtained. Male and female mice $(n=3 /$ group/sex $)$ were randomly separated into control and treated groups. After three hours of food fasting, a single $2000 \mathrm{mg} / \mathrm{kg}$ dose of LPE $(0.2 \mathrm{~mL})$ was administrated orally (gavage) to each animal. The control group only received LPE vehicle (sunflower oil) $(0.2 \mathrm{~mL})$. After exposure, clinical observations were conducted at 5, 15 and $30 \mathrm{~min}$, and every hour up to the twelfth hour of the first day. Posteriorly, the mice were examined once a day for an additional 13 days. The safety of the $2000 \mathrm{mg} / \mathrm{kg}$ dose of LPE was subsequently confirmed in other male and female mice as recommended by OECD Guideline 423 .

\section{Subchronic toxicity evaluation of LPE}

Female mice were used in the subchronic toxicity test based on OECD Guideline 407 - Repeated Dose 28-day Toxicity Study in Rodents (2008). The animals were randomly divided into five groups ( $\mathrm{n}=5 /$ group) and, after three hours of food fasting, they were treated daily with vehicle (sunflower oil) or doses of LPE $(6.25,25$, 
100,400 or $1000 \mathrm{mg} / \mathrm{kg}$ ). The extract and its vehicle were administered orally. During the test, the animals were observed daily and weighed weekly to adjust the dose when needed. After exposure, the mice were anesthetized and approximately $1 \mathrm{~mL}$ of blood was removed by cardiac puncture. The animals were immediately euthanized. Aliquots of blood samples were divided between a tube without anticoagulants and another containing EDTA for biochemical and hematological assays, respectively. In addition, organs were removed for macroscopic and histopathological analyses.

\section{Laboratory test}

\section{Hematological analysis}

A hematological examination was undertaken using an ABX Micros 60 apparatus (Horiba, São Paulo, SP, Brazil). The parameters analyzed were red blood cells, hemoglobin, hematocrit, platelets and global leukocytes. Reticulocyte counting was also determined using brilliant cresyl blue dye (Nakage et al., 2005). To prepare the slides, $50 \mu \mathrm{L}$ of the blood of each animal was incubated with the same amount of dye for 15 minutes at $37^{\circ} \mathrm{C}$. Then the number of reticulocytes per 1000 erythrocytes was determined microscopically (1000x magnification) in a blind test. A reticulocyte was identified as a red blood cell containing at least two granules of reticulum (Lamchiagdhase, Pattanapanyasat, Muangsup, 2000).

\section{Biochemical analysis}

Blood samples without anticoagulants were centrifuged to obtain a serum pool, which was submitted to a biochemical examination. The following biochemical parameters were employed using LabmaxPlenno (Labtest, Belo Horizonte, MG, Brazil) equipment: alanine aminotransferase (ALT), aspartate aminotransferase (AST), urea, creatinine, albumin, total cholesterol and proteins, while the electrolytes $\left(\mathrm{Na}^{+}\right.$and $\left.\mathrm{K}^{+}\right)$were evaluated using AVL 9180 Electrolyte Analyzer (InstruMed, Atlanta, GA, USA).

\section{Necropsy and histopathology}

A gross necropsy was conducted by visual inspection of all animals at the end of the treatment period. The following organs were collected, weighed and evaluated in terms of body weight percentage of each animal: brain, kidney, liver, heart, spleen and lung. These tissues were preserved in $10 \%$ buffered formalin to await the histopathological analysis.

For the histopathology evaluation, macroscopic cross sections of these organs were dehydrated in graded ethanol (70-100\%), cleared in xylene and then paraffinembedded. Paraffin-embedded tissue sections of $5 \mu \mathrm{m}$ thickness were obtained using a microtome (Leica RM 2155, Heidelberg, BW, Germany). After mounting, the slides were dewaxed in xylene, hydrated using graded ethanol and stained with hematoxylin and eosin (H\&E). The sections were observed with a light microscope (Axio Scope A 1 Carl Zeiss, Jena, TH, Germany) using a 40x objective and photographed using an AxioCam MRc Carl Zeiss camera and AxioVs40 V 4.7.2.0 Carl Zeis software.

\section{Immunohistochemistry for detecting Ki-67}

Paraffin-embedded liver and kidney sections of $3 \mu \mathrm{m}$ thickness were obtained and mounted on silane-coated microscope slides for immunohistochemistry to detect Ki-67 as described by Ávila et al. (2015).

\section{Statistical analysis}

The data were expressed as mean \pm standard deviation. Inter group variation was measured by the Analysis of Variance (ANOVA) followed by the Bonferroni test. Statistical significance was established as $\mathrm{p}<0.05$.

\section{RESULTS}

\section{Acute oral toxicity evaluation of LPE}

In the acute toxicity assay, the experimental groups of male and female mice were exposed to a single $2000 \mathrm{mg} / \mathrm{kg}$ dose of the LPE. During the 14 days after evaluation, only one female mouse appeared apathetic and died. The safety of this dose was subsequently defined through another experiment and no death or clinical signs of toxicity were observed in the mice. Thus, the $\mathrm{DL}_{50}$ of LPE was classified as category 5 $\left(\mathrm{LD}_{50}>2000-5000 \mathrm{mg} / \mathrm{kg}\right)$ of the Globally Harmonized Classification System for Chemical Substances and Mixtures (GHS), in agreement with OECD Guideline 423 (2001). For the subsequent assay of subchronic toxicity assessment, females were used because of their possible susceptibility to LPE.

\section{Subchronic toxicity evaluation of LPE}

During the 28-day subchronic toxicity assay, neither death nor clinical signs of toxicity in the mice exposed to LPE $(6.25,25,100,400$ or $1000 \mathrm{mg} / \mathrm{kg})$ were observed. Moreover, no significant abnormality in feces, hair, body weight loss or behavior was identified in comparison with the control group. 
In terms of the hematological analysis, the percentage of reticulocytes showed a significant increase for the higher doses of LPE, at 100, 400 and $1000 \mathrm{mg} / \mathrm{kg}(\mathrm{p}<0.05)$. The other parameters did not show any significant alterations for any of the extract doses (Table I).

The biochemical parameters of the pooled serum are summarized in Table II. In animals treated with the three lower doses of LPE $(6.25,25$ and $100 \mathrm{mg} / \mathrm{kg})$, the levels of total cholesterol, and hepatic and renal biomarkers were similar to those of the control values. On the other hand, the animals treated with 400 and $1000 \mathrm{mg} / \mathrm{kg}$ of LPE showed a tendency towards increase in levels of AST, ALT (especially at $1000 \mathrm{mg} / \mathrm{kg}$ ), total proteins, albumin, urea and total cholesterol, while creatinine showed a tendency towards reduction when compared to those of the control values. In parallel, $\mathrm{K}^{+}$electrolyte levels were similar to those of the control group, whereas $\mathrm{Na}^{+}$levels were normal at lower doses. However, with doses of 400 and $1000 \mathrm{mg} / \mathrm{kg}$, the levels of these electrolytes were reduced.
As regards organ weight analysis, only animals treated with $1000 \mathrm{mg} / \mathrm{kg}$ of LPE showed a significant reduction in liver weight $(\mathrm{p}<0.001)$, while for the other organs analyzed (brain, kidney, heart, spleen and lung) no changes were observed in the groups treated when compared to the control (Table III). In addition, macroscopy and histopathology evaluation presented no abnormality in organs of the groups treated. These included the kidney and liver, the two major organs of metabolism and excretion of xenobiotics. In these, no changes were observed in the Ki-67 expression, which shows that the LPE probably did not alter renal or hepatic proliferative activity (Figure 1).

\section{DISCUSSION}

Several studies have highlighted the medicinal properties of L. pacari, corroborating its use in popular medicine. Phenolic compounds (e.g. flavonoids and tannins, and in particular the main active compound of LPE,

TABLE I - Effects of daily oral treatment of female mice with LPE $(6.25,25,100,400$ or $1000 \mathrm{mg} / \mathrm{kg} /$ day $)$ during 28 days in the hematological parameters

\begin{tabular}{lcccccc}
\hline Groups & $\begin{array}{c}\text { Red blood cell } \\
\left(\mathbf{1 0}^{\mathbf{6}} / \mathbf{m m}^{\mathbf{3}}\right)\end{array}$ & $\begin{array}{c}\text { Reticulocyte } \\
\mathbf{( \% )}\end{array}$ & $\begin{array}{c}\text { Hemoglobin } \\
\mathbf{( g / \mathbf { d } )}\end{array}$ & $\begin{array}{c}\text { Hematocrit } \\
\mathbf{( \% )}\end{array}$ & $\begin{array}{c}\text { Platelets } \\
\left(\mathbf{1 0}^{\mathbf{3}} / \mathbf{m m}^{\mathbf{3}} \mathbf{)}\right.\end{array}$ & $\begin{array}{c}\text { Global } \\
\text { leukocytes } \\
\left(\mathbf{1 0}^{3} / \mathbf{m m}^{3}\right)\end{array}$ \\
\hline Control & $4.54 \pm 0.64$ & $1.66 \pm 0.39$ & $6.31 \pm 0.46$ & $21.94 \pm 2.86$ & $404.44 \pm 41.73$ & $4.54 \pm 0.64$ \\
$6.25 \mathrm{mg} / \mathrm{kg}$ & $4.68 \pm 0.19$ & $2.0 \pm 0.20$ & $6.35 \pm 0.37$ & $22.98 \pm 1.21$ & $456.0 \pm 42.0$ & $4.68 \pm 0.19$ \\
$25 \mathrm{mg} / \mathrm{kg}$ & $5.19 \pm 0.23$ & $2.10 \pm 0.20$ & $6.76 \pm 0.47$ & $24.70 \pm 1.52$ & $396.20 \pm 70.96$ & $5.19 \pm 0.23$ \\
$100 \mathrm{mg} / \mathrm{kg}$ & $4.54 \pm 0.25$ & $2.75 \pm 0.07^{\mathrm{a}}$ & $6.15 \pm 0.43$ & $21.30 \pm 1.15$ & $430.25 \pm 66.75$ & $4.54 \pm 0.25$ \\
$400 \mathrm{mg} / \mathrm{kg}$ & $4.10 \pm 0.31$ & $2.60 \pm 0.53^{\mathrm{a}}$ & $6.14 \pm 0.39$ & $19.66 \pm 1.23$ & $339.0 \pm 64.0$ & $4.10 \pm 0.31$ \\
$1000 \mathrm{mg} / \mathrm{kg}$ & $4.66 \pm 0.29$ & $2.85 \pm 0.30^{\mathrm{a}}$ & $5.85 \pm 0.28$ & $22.63 \pm 1.08$ & $368.33 \pm 117.88$ & $4.66 \pm 0.29$ \\
\hline
\end{tabular}

The data are expressed as the mean \pm standard deviation of five animals. ${ }^{a} \mathrm{p}<0.05$ vs. control. One-way ANOVA and Bonferroni's test.

TABLE II - Evaluation of serum pool biochemical parameters after daily oral treatment of female mice with LPE $(6.25,25,100$, 400 or $1000 \mathrm{mg} / \mathrm{kg} /$ day) during 28 days

\begin{tabular}{lccccccccc}
\hline Groups & ALT (U/L) & AST (U/L) & $\begin{array}{c}\text { Albumin } \\
\text { (g/dL) }\end{array}$ & $\begin{array}{c}\text { Total } \\
\text { Proteins } \\
(\mathbf{g} / \mathbf{d L})\end{array}$ & $\begin{array}{c}\text { Urea } \\
(\mathbf{m g} / \mathbf{d L})\end{array}$ & $\begin{array}{c}\text { Creatinine } \\
(\mathbf{m g} / \mathbf{d L})\end{array}$ & \multicolumn{2}{c}{ Electrolytes (mEq/L) } & $\begin{array}{c}\text { Total } \\
\text { Cholesterol } \\
(\mathbf{m g} / \mathbf{d L})\end{array}$ \\
\hline Control & 34 & 201.5 & 2.3 & 5.8 & 50.5 & 0.33 & 5.0 & 161 & 90 \\
$6.25 \mathrm{mg} / \mathrm{kg}$ & 34 & 218 & 2.1 & 5.6 & 51 & 0.35 & $*$ & $*$ & 98 \\
$25 \mathrm{mg} / \mathrm{kg}$ & 32 & 183 & 1.9 & 5.1 & 45 & 0.33 & 4.8 & 168 & 74 \\
$100 \mathrm{mg} / \mathrm{kg}$ & 41 & 184 & 2.2 & 5.8 & 56 & 0.36 & 5.5 & 172 & 94 \\
$400 \mathrm{mg} / \mathrm{kg}$ & 51 & 210 & 2.9 & 7.3 & 57 & 0.31 & 5.6 & 152 & 125 \\
$1000 \mathrm{mg} / \mathrm{kg}$ & 43 & 309 & 2.6 & 6.7 & 64 & 0.21 & 5.1 & 152 & 122 \\
\hline
\end{tabular}

Data represent the analysis of a sample pool, since the reduced amount of serum obtained. The asterisk $(*)$ represents electrolyte levels not detected in the sample 
TABLE III - Relative organ weights of female mice after daily oral treatment with LPE $(6.25,25,100,400$ or $1000 \mathrm{mg} / \mathrm{kg} / \mathrm{day})$ during 28 days

\begin{tabular}{lcccccc}
\hline Groups & Brain (\%) & Kidney (\%) & Liver (\%) & Heart (\%) & Spleen (\%) & Lung (\%) \\
\hline Control & $1.31 \pm 0.12$ & $1.10 \pm 0.04$ & $4.68 \pm 0.26$ & $0.61 \pm 0.19$ & $0.33 \pm 0.04$ & $0.84 \pm 0.16$ \\
$6.25 \mathrm{mg} / \mathrm{kg}$ & $1.43 \pm 0.05$ & $1.06 \pm 0.06$ & $4.80 \pm 0.19$ & $0.42 \pm 0.02$ & $0.38 \pm 0.09$ & $0.95 \pm 0.31$ \\
$25 \mathrm{mg} / \mathrm{kg}$ & $1.30 \pm 0.10$ & $1.12 \pm 0.06$ & $4.56 \pm 0.24$ & $0.44 \pm 0.03$ & $0.37 \pm 0.05$ & $0.92 \pm 0.15$ \\
$100 \mathrm{mg} / \mathrm{kg}$ & $1.25 \pm 0.15$ & $1.03 \pm 0.07$ & $4.71 \pm 0.14$ & $0.55 \pm 0.11$ & $0.36 \pm 0.05$ & $0.82 \pm 0.06$ \\
$400 \mathrm{mg} / \mathrm{kg}$ & $1.21 \pm 0.16$ & $1.0 \pm 0.07$ & $4.39 \pm 0.32$ & $0.49 \pm 0.04$ & $0.29 \pm 0.03$ & $0.97 \pm 0.16$ \\
$1000 \mathrm{mg} / \mathrm{kg}$ & $1.50 \pm 0.10$ & $1.01 \pm 0.06$ & $4.15 \pm 0.17^{\mathrm{a}}$ & $0.59 \pm 0.16$ & $0.25 \pm 0.04$ & $0.86 \pm 0.10$ \\
\hline
\end{tabular}

Data are expressed as the mean \pm standard deviation of five organs animals. ${ }^{a} \mathrm{p}<0.001 v s$. control. Two-way ANOVA and Bonferroni test.

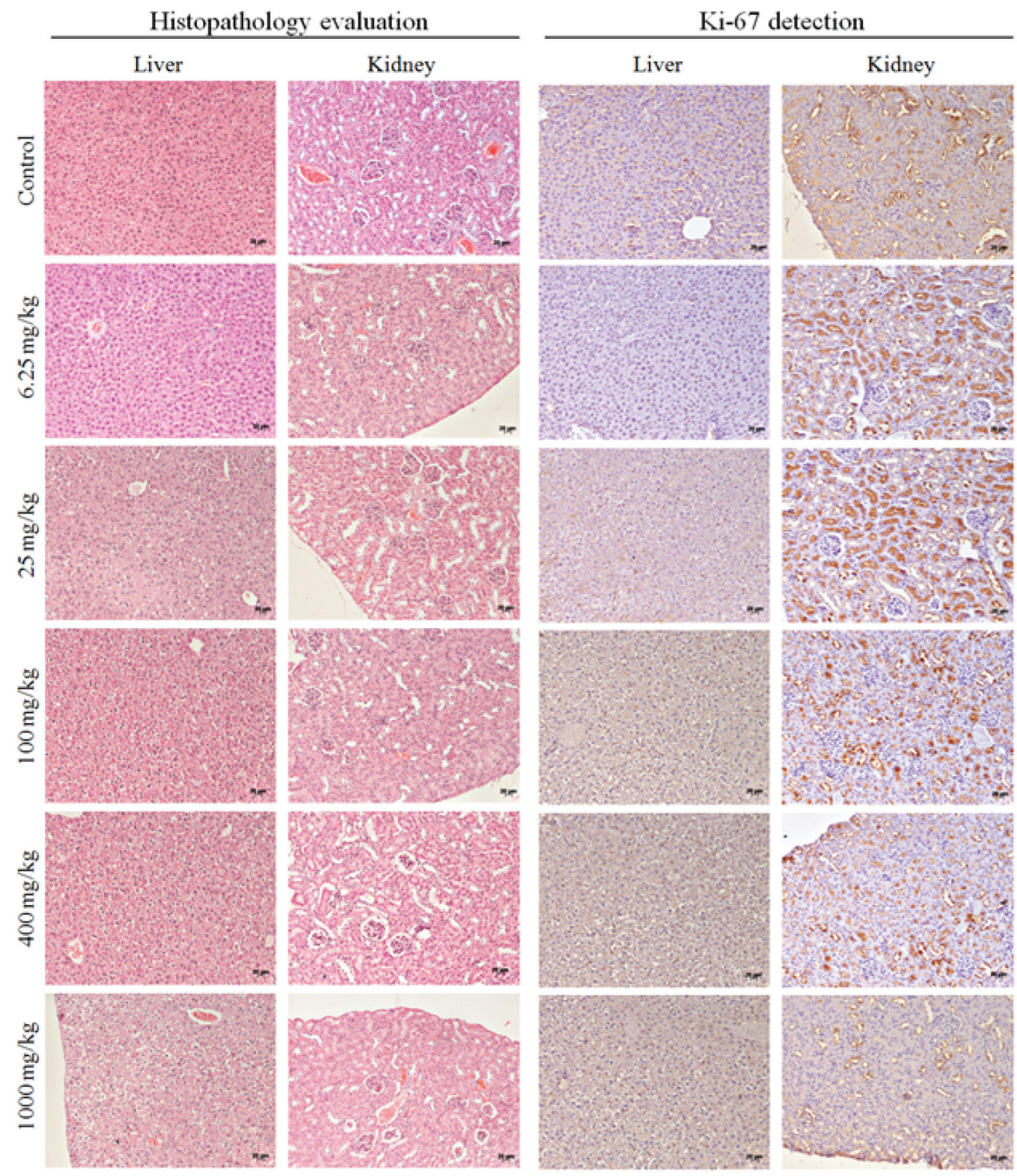

FIGURE 1 - Histopathology and Ki-67 detection representative photomicrographs of kidney and liver sections of mice treated orally with LPE $(6.25,25,100,400$ or $1000 \mathrm{mg} / \mathrm{kg} /$ day $)$ for 28 days. 
ellagic acid) have been shown to be fundamental for the biological activities found in L. pacari (Solon et al., 2000, Sampaio et al., 2011). However, no toxicity studies had been well conducted to demonstrate the safety of this plant.

In the first observation of this study, the acute oral systemic toxicity evaluation of a single $2000 \mathrm{mg} / \mathrm{kg}$ dose of LPE showed no toxicity in either the male or female mice studied. Thus, the $\mathrm{DL}_{50}$ of LPE was classified as GHS category $5\left(\mathrm{LD}_{50}>2000-5000 \mathrm{mg} / \mathrm{kg}\right)$, as proposed by the OECD evaluation criteria (2002). Although products classified in this category are commonly considered as having low acute toxicity, continued use can produce different biological effects and therefore should be investigated. In this regard, a repeated dose 28-day toxicity study of LPE $(6.25,25,100,400$ or $1000 \mathrm{mg} / \mathrm{kg})$ was evaluated through clinical, biochemical, histopathological/ immunocytochemical and hematological analyses to examine possible toxic effects in tissues, specifically hepatic and renal effects (OECD, 2008).

The results indicated that a daily oral administration of $6.25,25$ or $100 \mathrm{mg} / \mathrm{kg}$ of LPE for 28 days did not alter the biochemistry, hematology or organs of the animals exposed. In addition, the data suggested that 400 and $1000 \mathrm{mg} / \mathrm{kg}$ of LPE induced alterations in the biochemical parameters of the animals, especially in transaminase levels, hematological parameters and in liver weight. However, these two higher doses do not represent the amount commonly used in folk medicine and, in this study, they only illustrate an overdose condition, as recommended by OECD (2008). In a study of the therapeutic assessment of LPE in the eradication of Helicobacter pylori, capsules with $500 \mathrm{mg}$ powder of $20 \%$ methanolic extract of L. pacari were orally administered twice a day for 14 days to patients with dyspeptic complaints and positive for H. pylori. This treatment did not eradicate H. pylori; however, it was well-tolerated and individuals reported relief of symptoms (Menezes et al., 2006).

Macroscopic evaluations of the organs of animals treated with LPE $(6.25-1000 \mathrm{mg} / \mathrm{kg})$ did not show any alteration. Furthermore, no change was observed in the expression of the Ki-67 cell proliferation indicator in the kidney or liver tissues, which suggests that LPE did not promote changes in the proliferative activity of these organs. Several studies have reported the protective effects of ellagic acid, the main active compound responsible for the biological effects of LPE, and of other Lythraceae family species on liver (Baravalia, Chanda, 2011; GarcíaNiño, Zazueta, 2015; Kang et al., 2016; Salem et al., 2016) and kidney (Priya, Sabu, Jolly, 2007; Basha, Saumya, 2013; El-Garhy et al., 2014; Ayhanci et al., 2015) injuries triggered by xenobiotic-induced oxidative stress.
In terms of the hematological analysis, animals treated with 100, 400 and $1000 \mathrm{mg} / \mathrm{kg}$ of LPE showed a significant increase in reticulocytes, which demonstrates a possible proliferative effect on blood cells. In another study, Lima et al. (2013) presented the antigenotoxic and anticytotoxic activities of LPE on reticulocytes obtained from mouse bone marrow through the micronucleus assay. Corroborating these findings, Grossi et al. (2014) also showed that ellagic acid did not reveal any negative effect on the bone marrow hematopoietic cells. Moreover, a 90-day subchronic toxicity study showed no mortality, clinical signs, biochemical or histopathological changes in F344 male or female rats treated with different doses of ellagic acid (Tasaki et al., 2008).

In conclusion, the acute oral toxicity evaluation of the LPE showed no toxicity in either female or male mice, showing $\mathrm{LD}_{50}(>2000-5000 \mathrm{mg} / \mathrm{kg}$ ) classified as GHS category 5 . In addition, the results indicate that a daily oral administration of two higher doses of LPE (400 and $1000 \mathrm{mg} / \mathrm{kg}$ ) for 28 days did not produce hematotoxicity, but biochemical alterations in the liver and renal function, without any macroscopic/microscopic or proliferative changes, were found. In view of the fact that there is no scientific knowledge about the toxicological profile of the L. pacari plant, it should be used with caution, particularly in larger doses over longer periods and also in combination with other medication.

\section{ACKNOWLEDGEMENTS}

This study was supported by Fundação de Apoio à Pesquisa do Estado de Goiás (FAPEG), Conselho Nacional de Desenvolvimento Cientifico e Tecnológico (CNPq), and Coordenação de Aperfeiçoamento de Pessoal de Nivel Superior (CAPES).

\section{DECLARATION OF INTEREST}

The authors declare no conflict of interest.

\section{REFERENCES}

Ávila PHM, Ávila RI, Santos Filho EX, Bastos CCC, Batista AC, Mendonça EF, et al. Mucoadhesive formulation of Bidens pilosa L. (Asteraceae) reduces intestinal injury from 5-fluorouracilinduced mucositis in mice. Toxicol Rep. 2015;2:563-73.

Ayhanci A, Cengiz M, Mehtap Kutlu H, Vejselova D. Protective effects of ellagic acid in D-galactosamine-induced kidney damage in rats. Cytotechnology. 2016;68(5):1763-70. 
Baravalia Y, Chanda S. Protective effect of Woodfordia fruticosa flowers against acetaminophen-induced hepatic toxicity in rats. Pharm Biol. 2011;49(8):826-32.

Basha MP, Saumya SM. Influence of fluoride on streptozotocin induced diabetic nephrotoxicity in mice: protective role of Asian ginseng (Panax ginseng) \& banaba (Lagerstroemia speciosa) on mitochondrial oxidative stress. Indian J Med Res. 2013;137(2):370-9.

El-Garhy AM, Abd El-Raouf OM, El-Sayeh BM, Fawzy HM, Abdallah DM. Ellagic acid antiinflammatory and antiapoptotic potential mediate renoprotection in cisplatin nephrotoxic rats. J Biochem Mol Toxicol. 2014;28(10):472-9.

Galdino PM, Nascimento MVM, Sampaio BL, Ferreira RN, Paula JR, Costa EA. Antidepressant-like effect of Lafoensia pacari A. St.-Hil. ethanolic extract and fractions in mice. J Ethnopharmacol. 2009;124(3):581-85.

Galdino PM, Carvalho AA, Florentino IF, Martins JL, Gazola AC, de Paula JR, et al. Involvement of monoaminergic systems in the antidepressant-like properties of Lafoensia pacari A. St. Hil. J Ethnopharmacol. 2015;170:218-25.

García-Niño WR, Zazueta C. Ellagic acid: Pharmacological activities and molecular mechanisms involved in liver protection. Pharmacol Res. 2015;97:84-103.

Grossi MR, Berni A, Pepe G, Filippi S, Meschini R, Papeschi $\mathrm{C}$, et al. Evaluation of the effects of ellagic acid (EA) on 7,12-dimethylbenz( $\alpha$ ) anthracene (DMBA) induced micronuclei in mammalian cells in vitro and in vivo. Toxicol Lett. 2014;224(2):240-45.

Hubrecht R, Kirkwood J. The care and management of laboratory and other research animals. United Kingdom: WileyBlackwell; 2010.

Kang I, Espín JC, Carr TP, Tomás-Barberán FA, Chung S. Raspberry seed flour attenuates high-sucrose diet-mediated hepatic stress and adipose tissue inflammation. J Nutr Biochem. 2016;32:64-72.

Lamchiagdhase P, Pattanapanyasat K, Muangsup W. Reticulocyte counting in thalassemia using different automated technologies. Lab Hematol. 2000;6:73-8.

Lima MRF, Ximenes ECP, Luna JS, Sant'Ana AEG. The antibiotic activity of some Brazilian medicinal plants. Rev Bras Farmacogn. 2006a;16(3):300-6.
Lima MRF, Luna JS, Santos AF, Andrade MCC, Sant'Ana AEG, Genet J-P, et al. Antibacterial activity of some Brazilian medicinal plants. J Ethnopharmacol. 2006b;105:137-47.

Lima DCS, Silva CR, Sampaio BL, de Paula JR, Chen-Chen L. Antigenotoxic, and anticytotoxic activities of an ethanolic extract of Lafoensia pacari (Lythraceae) stem bark in bacteria and mice. Genet Mol Res. 2013;12(3):3887-96.

Marcondes DBS, Reichert CL, Andrade LF, Santos CAM, Weffort-Santos AM. Cytotoxicity and apoptogenic effects of Lafoensia pacari. J Ethnopharmacol. 2014;157:243-50.

Matos LG, Santos LR, Ferreira RN, Pontes IS, Paula JR, Costa EA. Anti-inflammatory, antinociceptive, and sedating effects of Lafoensia pacari aqueous extract. Pharm Biol. 2008;46(5):34146.

Menezes VM, Atallah AN, Lapa AJ, Catapani WR. Assessing the therapeutic use of Lafoensia pacari St. Hil. extract (mangavabrava) in the eradication of Helicobacter pylori: double-blind randomized clinical trial. Helicobacter. 2006;11(3):188-95.

Nakage AP, Santana AE, Cápua ML, Godoy AV. Characterization and quantification of blood cells from the umbilical cord of dogs. Vet Clin Pathol. 2005;34(4):394-96.

Nascimento MV, Galdino PM, Florentino IF, Sampaio BL, Vanderlinde FA, de Paula JR, et al. Antinociceptive effects of Lafoensia pacari A. St.-Hil. independent of anti-inflammatory activity of ellagic acid. J Nat Med. 2011;65(3-4):448-54.

OECD (Organization for Economic Cooperation and Development). Repeated dose 28 day toxicity study in rodents. Guideline for the Testing of Chemicals, n. 407; 2008.

OECD (Organization for Economic Cooperation and Development). Acute oral toxicity: acute toxic class method. Guideline for the Testing of Chemicals, n. 423; 2002.

Olfert ED, Cross BM, Mcwilliam AA. Guide to the care and use of experimental animals. Ottawa, Canada; 1993

Pereira EMR, Gomes RT, Freire NR, Aguiar EG, Brandão MGL, Santos VR. In vitro antimicrobial activity of Brazilian medicinal plant extracts against pathogenic microorganisms of interest to dentistry. Planta Med. 2011;77(4):401-4. 
Pereira LOM, Vilegas W, Tangerina MMP, Arunachalam K, Balogun SO, Orlandi-Mattos PE, et al. Lafoensia pacari A. St.-Hil.: wound healing activity and mechanism of action of standardized hydroethanolic leaves extract. J Ethnopharmacol. 2018;219:337-50.

Priya TT, Sabu MC, Jolly CI. Amelioration of cisplatin induced nephrotoxicity in mice by an ethyl acetate extract of Lagerstroemia speciosa (L). J Basic Clin Physiol Pharmacol. 2007;18(4):289-98.

Proença C, Oliveira RS, Silva AP. Flores e frutos do Cerrado. Brasília: Ed. UnB; 2000.

Queiroz e Silva SMF, Pinheiro SMB, Queiroz MVF, Pranchevicius MC, Castro JGD, Perim MC, et al. In vitro activity of crude extracts of two plant species in the Cerrado on yeast of the Candida SPP variety. Ciênc Saúde Colet. 2012;17(6):1649-56.

Rogerio AP, Sá-Nunes A, Albuquerque DA, Anibal FF, Medeiros AI, Machado ER, et al. Lafoensia pacari extract inhibits IL-5 production in toxocariasis. Parasite Immunol. 2003;25(7):393400.

Rogerio AP, Fontanari C, Melo MC, Ambrosio SR, de Souza GE, Pereira OS, et al. Anti-inflammatory, analgesic and antioedematous effects of Lafoensia pacari extract and ellagic acid. J Pharm Pharmacol. 2006;58(9):1265-73.

Rogerio AP, Fontanari C, Borducchi E, Keller AC, Russo M, Soares EG, et al. Anti-inflammatory effects of Lafoensia pacari and ellagic acid in a murine model of asthma. Eur J Pharmacol. 2008a;580(1-2):262-70.

Rogerio AP, Sá-Nunes A, Albuquerque DA, Soares EG, Faccioli LH. Anti-eosinophilic effect of Lafoensia pacari in toxocariasis. Phytomedicine. 2008b;15(5):348-57.
Rogerio AP, Sá-Nunes A, Faccioli LH. The activity of medicinal plants and secondary metabolites on eosinophilic inflammation. Pharmacol Res. 2010;62(4):298-307.

Salem AM, Mohammaden TF, Ali MA, Mohamed EA, Hassan HF. Ellagic and ferulic acids alleviate gamma radiation and aluminium chloride-induced oxidative damage. Life Sci. 2016;160:2-11.

Sampaio BL, Bara MTF, Ferri PH, Santos SC, Paula JR. Influence of environmental factors on the concentration of phenolic compounds in leaves of Lafoensia pacari. Rev Bras Farmacogn. 2011;21(6):1127-37.

Silva Junior IFS, Raimondi M, Zacchino S, Cechinel Filho V, Noldin VF, Rao VS, et al. Evaluation of the antifungal activity and mode of action of Lafoensia pacari A. St.-Hil., Lythraceae, stem-bark extracts, fractions and ellagic acid. Braz J Pharmacogn. 2010;20(3):422-28.

Solon S, Lopes L, Sousa Jr PT, Schmeda-Hirschmann G. Free radical scavenging activity of Lafoensia pacari. J Ethnopharmacol. 2000;72(1-2):173-78.

Tamashiro Filho P, Olaitan BS, Almeida DAT, Lima JC, MarsonAscêncio PG, Ascêncio SD, et al. Evaluation of antiulcer activity and mechanism of action of methanol stem bark extract of Lafoensia pacari A. St.-Hil. (Lytraceae) in experimental animals. J Ethnopharmacol. 2012;144(3):497-505.

Tasaki M, Umemura T, Maeda M, Ishii Y, Okamura T, Inoue $\mathrm{T}$, et al. Safety assessment of ellagic acid, a food additive, in a subchronic toxicity study using F344 rats. Food Chem Toxicol. 2008;46(3):1119-24

Received for publication on $11^{\text {th }}$ April 2017 Accepted for publication on $10^{\text {th }}$ July 2018 